\title{
Role of C5a-C5aR axis in the development of atherosclerosis
}

\author{
AN GuiPeng ${ }^{1,2}$, REN GuoRui $^{3}$, AN FengShuang $^{1,2} \&$ ZHANG Cheng ${ }^{1,2 *}$ \\ ${ }^{1}$ Key Laboratory of Cardiovascular Remodeling and Function Research, Ministry of Education and Ministry of Health, Shandong University \\ Qilu Hospital, Jinan 250012, China; \\ ${ }^{2}$ Department of Cardiology, Shandong University Qilu Hospital, Jinan 250012, China; \\ ${ }^{3}$ Department of Geriatrics, Qingdao Municipal Hospital, Qingdao 266071, China
}

Received May 9, 2014; accepted July 8, 2014

\begin{abstract}
Complement component 5a (C5a) is a 74 amino acid glycoprotein and an important proinflammatory mediator that is cleaved enzymatically from its precursor, $\mathrm{C} 5$, on activation of the complement cascade. C5a is quickly metabolised by carboxypeptidases, forming the less-potent C5a desArg. C5a and C5a desArg interact with their receptors (C5aR and C5L2), which results in a number of effects which are essential to the immune response. C5a has a broad range of biological effects throughout the human body because the widespread expression of C5a receptors throughout the human organs enables C5a and C5a desArg to elicit a broad range of biological effects. Recently, accumulating evidence in humans and experimental animal models shows that the C5a-C5aR axis is involved in the development of atherosclerosis lesions. The absence or blockade of C5aRs greatly reduces the formation of atherosclerotic lesions or wire-injury-induced neointima formation in atherosclerosis-prone mice. Serum $\mathrm{C} 5 \mathrm{a}$ level was related to the major adverse cardiovascular events in patients with advanced atherosclerosis and those with drug-eluting stent implantation. Thus, the C5a-C5aR axis may be a significant pathogenic driver of arteriosclerotic vascular disease, making C5a-C5aR inhibition an attractive therapeutic strategy.
\end{abstract}

C5a, C5a receptors, atherosclerosis

Citation: An GP, Ren GR, An FS, Zhang C. Role of C5a-C5aR axis in the development of atherosclerosis. Sci China Life Sci, 2014, 57: 790-794, doi: 10.1007/s11427-014-4711-5

Cardiovascular disease, a worldwide leading cause of mortality, is caused mainly by atherosclerosis, a chronic inflammatory disease of blood vessels driven by innate and adaptive immune responses [1,2]. As an important part of innate immunity, complement system has also been implicated in the development of atherosclerosis [3]. Various complement activation products, regulatory proteins, and complement receptors have been detected in human and animal atherosclerotic lesions, particularly in vulnerable and ruptured plaques, and deposition of C5b-9 has been shown to correlate with the extent of disease [4,5]. The role of complement in atherogenesis was also investigated with complement deficient animals. C3 deficiency was found to increase lipid-positive lesions in the mouse aorta and alter the plasma lipid profile [6]. However, contrasting results were obtained in C5-deficient ApoE knockout $\left(\mathrm{ApoE}^{--}\right)$ mice, with the extent of atherosclerotic lesions similar to that in complement-competent control mice [7].

The complement system consists of more than 30 proteins, mainly proteases, which are activated in response to tissue injury, invading pathogens or other foreign surfaces. This system could be activated by four pathways: the classical pathway, the lectin pathway, the alternative pathway and the extrinsic protease pathway (Figure 1). The classical pathway is activated by antibodies bound to antigens in immune complexes, and the lectin pathway is activated by microbial sugars such as mannose-binding lectin. The al-

*Corresponding author (email: zhangc@sdu.edu.cn) 


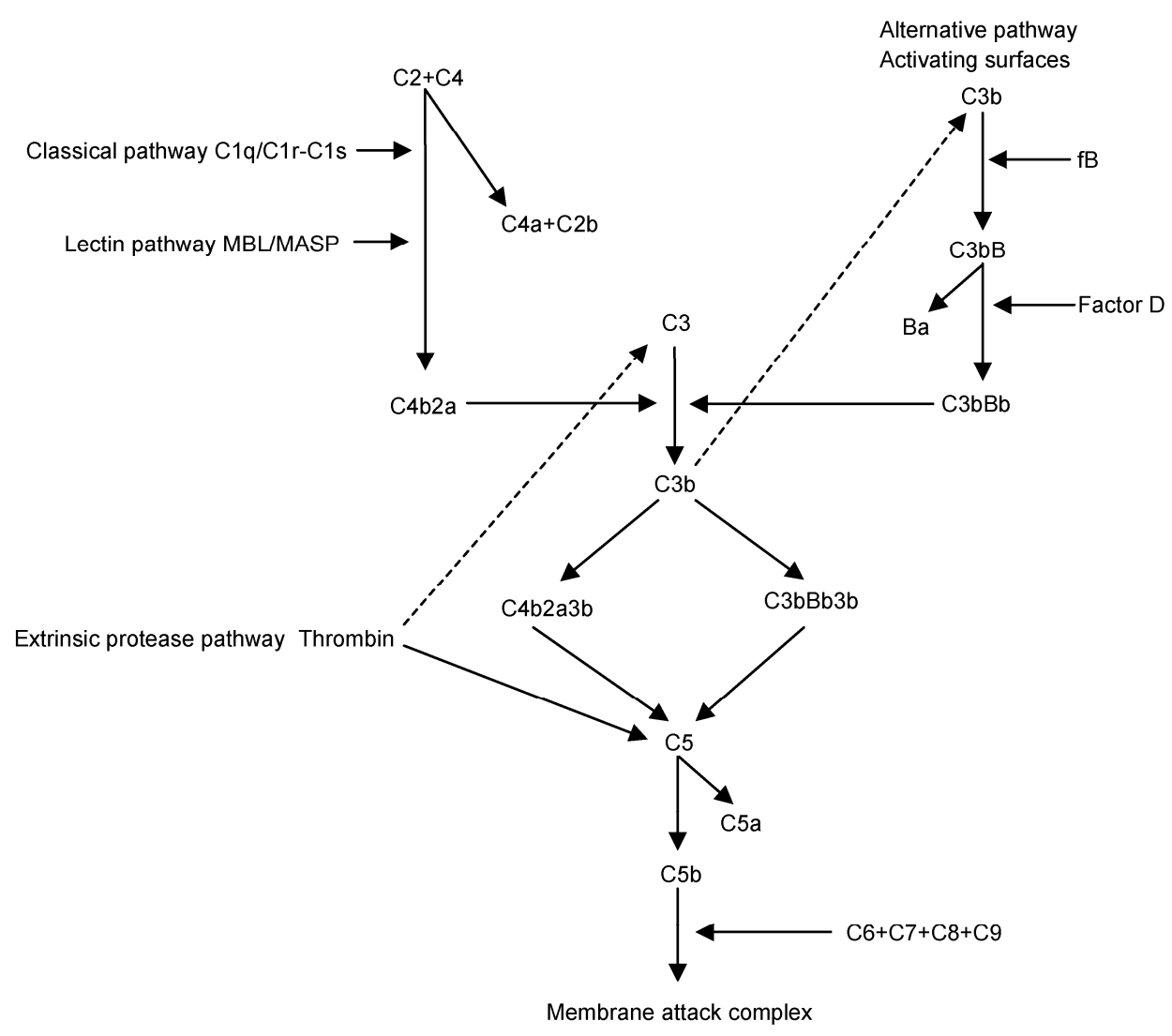

Figure 1 The four activation pathways of complement system: classical pathway, lectin pathway, alternative pathway and the extrinsic protease pathway.

ternative pathway can be activated by foreign surfaces or by spontaneous hydrolysis of $\mathrm{C} 3$. The extrinsic protease pathway involves direct cleavage of $\mathrm{C} 3$ and $\mathrm{C} 5$ by proteases such as thrombin [8].

Protease C5-convertase, which is produced in the procedure of complement activation, cleaves complement component C5 into C5a and C5b fragments. C5a is one of the major biologically active components of the complement system and exerts its functions mainly via the canonical C5a receptor (C5aR, CD88) [9,10]. Recently, the C5a-C5aR axis has been implicated in the development of atherosclerotic lesions. This review gives an outline of current knowledge of the role of the C5a-C5aR axis in atherosclerosis and therapeutic strategies that may be developed to combat its pro-atherogenic effects.

\section{Structure and functions of C5a and C5a re- ceptors}

$\mathrm{C} 5$, the precursor of C5a, is a 1676 amino acid protein whose gene is located at $9 \mathrm{q} 33-9 \mathrm{q} 34$. It is mainly produced by liver hepatocytes, although cells such as macrophages can independently synthesize and secrete C5 and thus may be local sources of C5a generation [11]. C5a is a glycoprotein of 74 amino acids $(\approx 11 \mathrm{kD})$ released from the al- pha-chain of C5 during complement activation. C5a has four anti-parallel alpha helices connected by peptide loops and stabilized by three critical disulphide linkages. Its agonist activity is derived from its C-terminal region, which assumes an elongated 1.5-turn helix that spans residues 69-74 and is attached to the helical core by a four-residue loop. It is a potent bioactive molecule that can act on its high affinity binding transmembrane receptors, C5aR/CD88 and C5L2, which are expressed by a wide variety of cell types throughout the human body $[10,12]$. Once plasma C5a is released from its precursor $\mathrm{C} 5$, plasma carboxypeptidases rapidly metabolize $\mathrm{C} 5 \mathrm{a}$ by cleaving the $\mathrm{C}$-terminal arginine to a less potent form, C5a desArg. C5a desArg has reduced potency as compared with $\mathrm{C} 5 \mathrm{a}$, which is in line with a reduced binding affinity for the classical $\mathrm{C} 5 \mathrm{a}$ receptor, CD88 [13].

C5a binds with similar high affinity to CD88 and C5L2. Both of these receptors are glycosylated, 7-transmembrane spanning proteins with molecular weights of about $45 \mathrm{kD}$. CD88 is a G-protein-coupled signaling receptor, but C5L2 is unable to couple to $G$ proteins because of lack of critical intracellular amino acid motifs. CD88 and C5L2 share about $35 \%$ sequence homology and are located in the same region of chromosome 19 (19q13.3-19q13.4) [14]. Both receptors are expressed on immune as well as non-immune cells; however, C5L2 is expressed at lower levels as com- 
pared with CD88. CD88 activation leads to increased intracellular calcium levels and activation of intracellular signaling cascades accompanied by a number of functional responses such as recruitment and activation of inflammatory cells, production of cytokines and chemokines, and release of granule-based enzymes [15,16]. On the other hand, C5L2 may act as a non-signaling decoy receptor regulating the extracellular bioavailability of C5a, thereby limiting the pro-inflammatory response of C5a. However, recently C5L2 was also found to facilitate C5a signaling in neutrophils, macrophages and fibroblasts. In addition, recent studies showed that C5L2 has a pro-inflammatory role in experimental sepsis and allergic asthma and may also control the development of Th17 cells [17].

\section{Expression of the C5a-C5aR axis in athero- sclerosis}

Complement components have been detected in atherosclerotic lesions, from the fatty streak through to complicated advanced plaques, but not in normal arteries [3]. C5 (the precursor of C5a and C5b-9/membrane attack complex) is expressed at both mRNA and protein levels in atherosclerotic arteries [18]. C5a has also been detected by immunohistochemical analysis of human coronary plaques, and a high circulating level of C5a was found in patients with advanced atherosclerosis $[19,20]$. The canonical C5a receptor, $\mathrm{CD} 88$, is expressed by various cell types found in hu- man atherosclerotic plaque, including immune cells (such as macrophage and mast cells) and non-immune cells (smooth muscle cells and endothelial cells). In addition, increased expression of CD88 was detected in aortas in atherosclerotic-prone mice, and this increase coincided with atherosclerotic lesion development [21]. Although mRNA expression of C5L2 in aortas was lower in $A p o E^{-1-}$ mice than wild-type mice, prominent C5L2 expression in advanced atherosclerotic lesions was found in human beings and its level was directly correlated with local levels of proinflammatory cytokines $[21,22]$.

\section{Influence of C5a-C5aR activation on pro- atherogenic cells}

Although little is known about the influence of C5a on atherogenesis, activation of CD88 is known to have a range of biological effects that may contribute to the atherogenic process (Figure 2). C5a is a strong chemotactic factor for monocytes, T lymphocytes and mast cells [23]. Endothelial cells showed enhanced surface and mRNA expression of C5aR on stimulation with lipopolysaccharide, interferon $\gamma$, and interleukin 6 (IL-6), concomitant with up-regulation of macrophage inflammatory protein 2 and monocyte chemoattractant protein 1 [24]. C5a may also affect the migration of inflammatory cells into the intima by inducing the expression of adhesion molecules such as P-selectin, Eselectin, intracellular adhesion molecule 1 and vascular cell

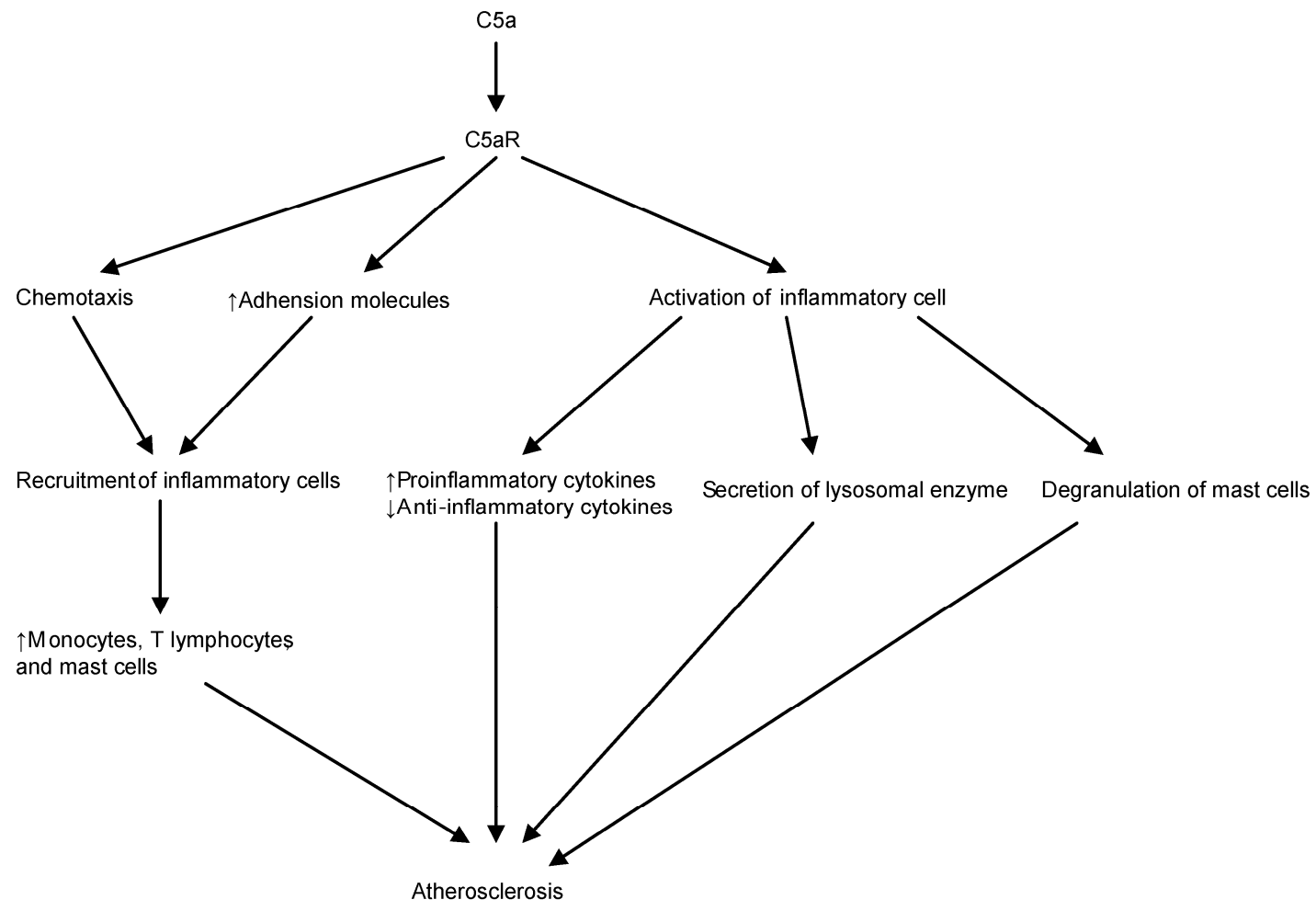

Figure 2 The molecular mechanism of the proatherogenic role of C5a. 
adhesion molecule 1 in endothelial or smooth muscle cells [25-27]. In addition, C5a can directly activate inflammatory cells, causing the release of cytokines, expression of related receptors, secretion of lysosomal enzymes from macrophages, proliferation of $\mathrm{T}$ lymphocytes, and degranulation of mast cells [28]. Recently, C5a was found involved in cholesterol crystal-induced production of cytokines (including IL-1 $\beta$ and tumor necrosis factor), complement receptor 3 , reactive oxygen species and active caspase 1 [29].

\section{Animal experimental evidence for the role of C5a-C5aR in atherosclerosis}

The role of C5a-C5aR axis in atherogenesis was investigated in atherosclerotic-prone mice. In a model of wireinduced endothelial denudation of the carotid artery, one-week treatment with C5aRA or anti-C5aR-blocking monoclonal antibody limited neointimal hyperplasia and reduced inflammatory cell content through inhibiting the expression of vascular cell adhesion molecule-1 [27]. Treating $A \mathrm{poE}^{-/-}$mice with a CD88 antagonist, PMX53, for 25 weeks reduced lesion size and lipid content in plaque by about $40 \%$ [21]. Immunization of mice with C5aR-derived peptides (designated as C5aR-P1 (aa 1-21) and C5aR-P2 (aa 19-31)) was effective in reducing early atherosclerotic lesion development by inducing a specific regulatory T-cell response as well as blockage of monocytes differentiating into macrophages. Besides, the combined peptide was more potential than either peptide alone in reducing atherosclerotic lesion formation. The molecular mechanism may be that vaccination with peptides promotes a major shift away from proinflammatory cytokines (i.e., TNF- $\alpha$ and IFN- $\gamma$ ) toward anti-inflammatory cytokines (IL-10 and TGF- $\beta$ ) [30]. In addition, C5a and C5a-receptor (CD88) expression was found to be up-regulated during vein graft disease in apolipoprotein E-deficient mice. C5a application accelerated vein graft lesion formation through mast cell activation, whereas treatment with a C5aR antagonist, PM205, resulted in decreased vein graft disease [31].

\section{Serum C5a level and the prognosis of athero- sclerosis}

Complement activation occurs in atherosclerotic lesions; particularly, complement component C5a has potent chemotactic and proinflammatory effects. The relationship between plasma levels of C5a and cardiovascular risk has been investigated. In a study of 471 patients, serum C5a level was found significantly associated with acute coronary syndrome [32]. As well, elevated C5a level may be associated with increased cardiovascular risk (myocardial infarction, percutaneous coronary interventions, coronary artery bypass graft, carotid revascularization, stroke, and death) in patients with advanced atherosclerosis after a median follow-up of 22 months [20]. C5a levels at baseline were significantly higher in patients showing stent restenosis at follow-up and significantly associated with angiographic late lumen loss, which is independent of other clinical and procedural risk factors [33]. A similar result was found in patients with balloon angioplasty of the superficial femoral artery [34]. The C5 rs17611 GG genotype was found associated with increased C5a plasma level and represents a risk factor of adverse cardiovascular outcome in male patients with carotid atherosclerosis [35]. In patients who underwent combined aortic valve replacement and coronary artery bypass grafting, the administration of an antibody against $\mathrm{C} 5$ (the precursor of C5a) was associated with decreased mortality at 180-day follow-up [36].

\section{Conclusion}

Although the precise role of the C5a-C5aR interaction in atherosclerosis remains the subject of continuing investigation, the papers that have emerged over the last year shows that the C5a-C5aR axis is an important factor in the development of atherosclerotic lesions. Targeting the generation of $\mathrm{C} 5 \mathrm{a}$ and $\mathrm{C} 5 \mathrm{~b}$ or inhibiting the two C5a receptors, therefore, becomes an attractive target for drug development.

The authors declare no competing interests.

This work was supported by the National Natural Science Foundation of China (81000125, 81000127), Specialized Research Fund for the Doctoral Program of Higher Education (20100131120057) and Promotive Research Fund for Young and Middle-aged Scientisits of Shandong Province (BS2012YY017).

1 Fredman G, Spite M. Recent advances in the role of immunity in atherosclerosis. Circ Res, 2013, 113: e111-114

2 Witztum JL, Lichtman AH. The influence of innate and adaptive immune responses on atherosclerosis. Annu Rev Pathol, 2014, 9: 73-102

3 Speidl WS, Kastl SP, Huber K,Wojta J. Complement in atherosclerosis: friend or foe? J Thromb Haemost, 2011, 9: 428-440

4 Niculescu F, Rus HG, Vlaicu R. Immunohistochemical localization of C5b-9, S-protein, C3d and apolipoprotein B in human arterial tissues with atherosclerosis. Atherosclerosis, 1987, 65: 1-11

5 Haskard DO, Boyle JJ, Mason JC. The role of complement in atherosclerosis. Curr Opin Lipidol, 2008, 19: 478-482

6 Buono C, Come CE, Witztum JL, Maguire GF, Connelly PW, Carroll $\mathrm{M}$, Lichtman $\mathrm{AH}$. Influence of $\mathrm{C} 3$ deficiency on atherosclerosis. Circulation, 2002, 105: 3025-3031

7 Patel S, Thelander EM, Hernandez M, Montenegro J, Hassing H, Burton C, Mundt S, Hermanowski-Vosatka A, Wright SD, Chao YS, Detmers PA. ApoE $E^{-/-}$mice develop atherosclerosis in the absence of complement component C5. Biochem Biophys Res Commun, 2001, 286: $164-170$

8 Walport MJ. Complement. First of two parts. N Engl J Med, 2001, 344: 1058-1066

9 Nishiura H. The alternative C5a receptor function. Adv Exp Med 
Biol, 2013, 735: 111-121

10 Woodruff TM, Nandakumar KS, Tedesco F. Inhibiting the C5-C5a receptor axis. Mol Immunol, 2011, 48: 1631-1642

11 Amara U, Rittirsch D, Flierl M, Bruckner U, Klos A, Gebhard F, Lambris JD, Huber-Lang M. Interaction between the coagulation and complement system. Adv Exp Med Biol, 2008, 632: 71-79

12 Manthey HD, Woodruff TM, Taylor SM, Monk PN. Complement component 5a (C5a). Int J Biochem Cell Biol, 2009, 41: 2114-2117

13 Burgi B, Brunner T, Dahinden CA. The degradation product of the C5a anaphylatoxin C5adesarg retains basophil-activating properties. Eur J Immunol, 1994, 24: 1583-1589

14 Monk PN, Scola AM, Madala P, Fairlie DP. Function, structure and therapeutic potential of complement C5a receptors. Br J Pharmacol, 2007, 152: 429-448

15 Ward PA. Functions of C5a receptors. J Mol Med (Berl), 2009, 87: 375-378

16 Riedemann NC, Guo RF, Ward PA. A key role of C5a/C5ar activation for the development of sepsis. J Leukoc Biolo, 2003, 74: 966-970

17 Li R, Coulthard LG, Wu MC, Taylor SM, Woodruff TM. C5L2: a controversial receptor of complement anaphylatoxin, C5a. FASEB J, 2013, 27: 855-864

18 Yasojima K, Schwab C, McGeer EG, McGeer PL. Generation of $\mathrm{C}$-reactive protein and complement components in atherosclerotic plaques. Am J Pathol, 2001, 158: 1039-1051

19 Speidl WS, Kastl SP, Hutter R, Katsaros KM, Kaun C, Bauriedel G, Maurer G, Huber K, Badimon JJ, Wojta J. The complement component $\mathrm{C} 5 \mathrm{a}$ is present in human coronary lesions in vivo and induces the expression of MMP-1 and MMP-9 in human macrophages in vitro. FASEB J, 2011, 25: 35-44

20 Speidl WS, Exner M, Amighi J, Kastl SP, Zorn G, Maurer G, Wagner O, Huber K, Minar E, Wojta J, Schillinger M. Complement component C5a predicts future cardiovascular events in patients with advanced atherosclerosis. Eur Heart J, 2005, 26: 2294-2299

21 Manthey HD, Thomas AC, Shiels IA, Zernecke A, Woodruff TM, Rolfe B, Taylor SM. Complement C5a inhibition reduces atherosclerosis in $\mathrm{ApoE}^{-/-}$mice. FASEB J, 2011, 25: 2447-2455

22 Vijayan S, Asare Y, Grommes J, Soehnlein O, Lutgens E, Shagdarsuren G, Togtokh A, Jacobs MJ, Fischer JW, Bernhagen J, Weber C, Schober A, Shagdarsuren E. High expression of C5L2 correlates with high proinflammatory cytokine expression in advanced human atherosclerotic plaques. Am J Pathol, 2014, 184: 2123-2133

23 Guo RF, Ward PA. Role of C5a in inflammatory responses. Annu Rev Immunol, 2005, 23: 821-852

24 Laudes IJ, Chu JC, Huber-Lang M, Guo RF, Riedemann NC, Sarma JV, Mahdi F, Murphy HS, Speyer C, Lu KT, Lambris JD, Zetoune FS, Ward PA. Expression and function of C5a receptor in mouse microvascular endothelial cells. J Immunol, 2002, 169: 5962-5970

25 Albrecht EA, Chinnaiyan AM, Varambally S, Kumar-Sinha C,
Barrette TR, Sarma JV, Ward PA. C5a-induced gene expression in human umbilical vein endothelial cells. Am J Pathol, 2004, 164: 849-859

26 Foreman KE, Vaporciyan AA, Bonish BK, Jones ML, Johnson KJ, Glovsky MM, Eddy SM, Ward PA. C5a-induced expression of P-selectin in endothelial cells. J Clin Invest, 1994, 94: 1147-1155

27 Shagdarsuren E, Bidzhekov K, Mause SF, Simsekyilmaz S, Polakowski T, Hawlisch H, Gessner JE, Zernecke A, Weber C. C5a receptor targeting in neointima formation after arterial injury in atherosclerosis-prone mice. Circulation, 2010, 122: 1026-1036

28 Oksjoki R, Kovanen PT, Pentikainen MO. Role of complement activation in atherosclerosis. Curr Opin Lipidol, 2003, 14: 477-482

29 Samstad EO, Niyonzima N, Nymo S, Aune MH, Ryan L, Bakke SS, Lappegard KT, Brekke OL, Lambris JD, Damas JK, Latz E, Mollnes TE, Espevik T. Cholesterol crystals induce complement-dependent inflammasome activation and cytokine release. J Immunol, 2014, 192: $2837-2845$

30 Lu X, Xia M, Endresz V, Faludi I, Mundkur L, Gonczol E, Chen D, Kakkar VV. Immunization with a combination of 2 peptides derived from the C5a receptor significantly reduces early atherosclerotic lesion in Ldlr (tm1Her) Apob (tm2Sgy) J mice. Arterioscler Thromb Vasc Biol, 2012, 32: 2358-2371

31 de Vries MR, Wezel A, Schepers A, van Santbrink PJ, Woodruff TM, Niessen HW, Hamming JF, Kuiper J, Bot I, Quax PH. Complement factor $\mathrm{C} 5 \mathrm{a}$ as mast cell activator mediates vascular remodelling in vein graft disease. Cardiovasc Res, 2013, 97: 311-320

32 de Hoog VC, Timmers L, Schoneveld AH, Wang JW, van de Weg SM, Sze SK, van Keulen JK, Hoes AW, den Ruijter HM, de Kleijn DP, Mosterd A. Serum extracellular vesicle protein levels are associated with acute coronary syndrome. Eur Heart J Acute cardiovasc Care, 2013, 2: 53-60

33 Speidl WS, Katsaros KM, Kastl SP, Zorn G, Huber K, Maurer G, Wojta J, Christ G. Coronary late lumen loss of drug eluting stents is associated with increased serum levels of the complement components C3a and C5a. Atherosclerosis, 2010, 208: 285-289

34 Speidl WS, Exner M, Amighi J, Mlekusch W, Sabeti S, Kastl SP, Zorn G, Maurer G, Wagner O, Huber K, Minar E, Wojta J, Schillinger M. Complement component C5a predicts restenosis after superficial femoral artery balloon angioplasty. J Endovasc Ther, 2007, 14: 62-69

35 Hoke M, Speidl W, Schillinger M, Minar E, Zehetmayer S, Schonherr M, Wagner O, Mannhalter C. Polymorphism of the complement 5 gene and cardiovascular outcome in patients with atherosclerosis. Eur J Clin Invest, 2012, 42: 921-926

36 Carrier M, Menasche P, Levy JH, Newman MF, Taylor KM, Haverich A, Chen JC, Shernan SK, Van de Werf F,van der Laan M, Todaro TG, Adams PX, Verrier ED. Inhibition of complement activation by pexelizumab reduces death in patients undergoing combined aortic valve replacement and coronary artery bypass surgery. J Thorac Cardiovasc Surg, 2006, 131: 352-356

Open Access This article is distributed under the terms of the Creative Commons Attribution License which permits any use, distribution, and reproduction in any medium, provided the original author(s) and source are credited. 